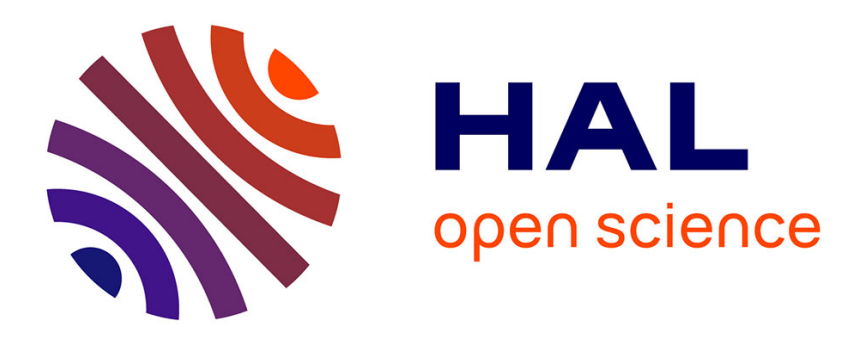

\title{
The Internet Bill of Rights project: The challenge of reconciliation between natural freedoms and needs for regulation
}

Francesca Musiani

\section{- To cite this version:}

Francesca Musiani. The Internet Bill of Rights project: The challenge of reconciliation between natural freedoms and needs for regulation. Fourth Annual GigaNet Symposium, Nov 2009, Sharm-el-Sheikh, Egypt. hal-00448248

HAL Id: hal-00448248

https://hal-mines-paristech.archives-ouvertes.fr/hal-00448248

Submitted on 18 Jan 2010

HAL is a multi-disciplinary open access archive for the deposit and dissemination of scientific research documents, whether they are published or not. The documents may come from teaching and research institutions in France or abroad, or from public or private research centers.
L'archive ouverte pluridisciplinaire HAL, est destinée au dépôt et à la diffusion de documents scientifiques de niveau recherche, publiés ou non, émanant des établissements d'enseignement et de recherche français ou étrangers, des laboratoires publics ou privés. 


\title{
The Internet Bill of Rights project: The challenge of reconciliation between natural freedoms and needs for regulation*
}

\author{
Francesca Musiani
}

Fourth Annual GigaNet Symposium

14 November 2009

Sharm-el-Sheikh, Egypt

\footnotetext{
* An earlier version of this paper, titled "The Internet Bill of Rights: A Way to Reconcile Natural Freedoms and Regulatory Needs?" has appeared in SCRIPTed: A Journal of Law, Technology and Society 6(2): 504-515 (August 2009).
} 


\begin{abstract}
Within broad debates on freedom, security and human rights on the Internet - carried on during recent years in national and international fora - the proposal for the creation and adoption of a Bill of Rights for the Internet has been the subject of uneven attention and mixed reviews. Taking stock of the renewed interest in the proposal showed by the Committee on Civil Liberties of the European Parliament, this article analyses the current state of the Internet Bill of Rights (IBR) project. The analysis briefly retraces the history and main promoters of the IBR proposal, outlines the rationale and perspectives behind it, and debates its promises, limits and future challenges, with a special focus on its potential as an instrument of reconciliation between natural freedoms and needs for regulation.
\end{abstract}

\title{
Contents
}

Introduction. The recognition of rights ...3

What rationale behind a constitution for the Internet? ...4

Basic principles between new and old rights: privacy as a case study ...6

...Towards an Internet Bill of Rights? ...8

The ongoing debate on the IBR ...9

What challenges and open issues for the IBR? ...12

Concluding remarks ...15

References ...16

Webography ...18

\begin{tabular}{l} 
About the author \\
Francesca Musiani is a PhD candidate at the Centre for the Sociology of Innovation (CSI) at \\
MINES ParisTech (associated with CNRS) in Paris, France, and a member of the scientific \\
committee in the Vox Internet II (FMSH-CSI-ENS LSH) research project. Her dissertation \\
research focuses on features and socio-economic implications of "alternative" P2P. She \\
holds a MA degree in International Law and the Settlement of Disputes from the United \\
Nations-mandated University for Peace in San José, Costa Rica, and a degree in \\
Organizational Communication from the University of Padova, Italy. \\
\hline
\end{tabular}




\section{Introduction. The recognition of rights}

Retracing the historical development of human rights and fundamental liberties, Gerhard Oestreich affirms that, enshrined in every basic right, are both the aims of the political and social ordering and the human understanding of self. ${ }^{1}$ With this image, the German author intends to convey the complexity of ethical, social, economic, historical and cultural relationships that underlie the attribution and recognition of every basic right. Every time that a new principle, right, rule or institution is acknowledged, the identity of the world we live in acquires some new facets.

This complexity is first revealed in the debate on the very existence of rights and on their foundations: the hypothesis that a core of inviolable, basic rights does exist carries with it a number of dilemmas. The natural eternity of such rights cannot be demonstrated, as their nature cannot, in fact, be defined; the essence of their existence cannot be shown; their intrinsic logic cannot be made explicit, as there is no one and only logic. However, it is not always true that if the existence of something cannot be affirmed, it has to be rejected only because proper instruments to categorically confirm it are lacking; the inviolability of the individual, moral and social is then seen as a historical and at the same time utopian value, a regulatory idea that must show the way ahead. ${ }^{2}$

A second level of complexity concerns the recognition of rights, that is not a steady and clear-cut process, for at least two main reasons: the difficulty to cope with regional differences, inequalities and social exclusion phenomena, and the trouble in pragmatically identifying not only what has been called the essential content of basic rights, but their limits of vulnerability as well. Moreover, if, as we have seen, the content of a right is hardly identifiable a priori, it means that, at a practical level, the content of a right is rather the result of the implementation of this right according to the history and features of a specific national, regional or cultural reality. It is therefore often difficult to point out which restrictions or regulations entail its intangible, essential core.

This article means to contribute to the debates on fundamental freedoms and security on the Internet, currently engaging with renewed interest within the Committee on Civil Liberties of the European Parliament, ${ }^{3}$ by attempting to locate the principles outlined above in the

\footnotetext{
${ }^{1}$ G Oestreich, Geschichte der Menschenrechte und Grundfreiheiten im Umriß (Berlin: Duncker \& Humblot, 1978), at 8.

${ }^{2}$ E Paolozzi, "Universalità e storicità dei diritti umani da Locke a Croce" (2000) Fondazione Luigi Einaudi, Scuola di Liberalismo, available at http://www.fondazione-einaudi.it/Download/123-127.pdf (accessed 11 May 2009).

${ }^{3}$ Information Policy, "European Parliament asks for respect of human rights on the Internet" (13 Apr 2009), available at http://www.i-policy.org/2009/04/european-parliament-asks-for-respect-of-human-rights-on-theinternet.html (accessed 22 April 2009). See also European Parliament, Report with a proposal for a European Parliament recommendation to the Council on strengthening security and fundamental freedoms on the Internet (2008/2160(INI)) (25 Feb 2009) available at http://www.europarl.europa.eu/sides/getDoc.do? type=REPORT\&reference=A6-2009-0103\&language=EN\#_part1_def11 (accessed 20 Apr 2009); European Parliament, Strengthening Fundamental Freedoms and Security on the Internet Public Hearing (5 Mar 2009) available at http://www.europarl.europa.eu/eplive/expert/shotlist page/20090304SHL50970/default en.htm
} 
specific context of the "new" rights brought along by the diffusion of the Internet in today's society, in a variety of sectors that include governance, education, management. The article analyses the current state of the proposal for the creation and adoption of a Bill of Rights for the Internet, and debates promises, challenges and limits of the project.

\section{What rationale behind a constitution for the Internet?}

Ever since the inception of the Web twenty years ago, a number of voices have been raised to define the Internet as the widest global public space of today's world, due to the millions of people every day exchanging messages, producing and receiving knowledge, building political and social participation, playing, selling and buying through and on it. ${ }^{4}$ An argument has also been made that the Internet, as the facility that ensures global interconnectivity, has to be treated as a common good. Alongside these arguments, sometimes blamed for their excessive "technological optimism", a discourse has developed on what it takes for the public space created by the Internet to be preserved. Is it necessary to actively try and prevent its privatisation or control by specific lobbies? Is the absence of regulation ultimately a way to leave the Internet at the mercy of authoritarian regimes or market laws? It should be taken into account, these "mild sceptics" warn, that what was originally the space of boundless possibilities and untamed freedom ${ }^{5}$ is increasingly also becoming a conflict arena that impacts upon individual and collective rights, where freedom is depicted as the enemy of security, and vice-versa. ${ }^{6}$

Regardless of the position one assumes in this controversy, it seems safe to acknowledge that these conflicts do exist - and they prompt, now more than ever, a thorough reflection on the opportunity for the Internet to find its rules and produce its institutions, and what it means and takes at a more practical level to "guarantee the respect of freedoms and rights for all its users", 7 despite the appealing but rather vague choice of words. A key contribution to the discussion of these issues is provided by the work of American scholars such as Jack Balkin on freedom of expression, ${ }^{8}$ John Palfrey on access ${ }^{9}$ and, especially, Lawrence Lessig

(accessed 20 Apr 2009).

${ }^{4}$ P Di Maggio et al, "Social Implications of the Internet” (2001) 27 Annual Review of Sociology, 307-336.

5 S Rodotà, "Una Costituzione per Internet" (2006) La Repubblica, available at http://www.repubblica.it/2006/06/sezioni/scienza e tecnologia/regole-internet/regole-internet/regoleinternet.html (accessed 20 Apr 2009).

${ }^{6}$ S Rodotà, "Perchè Internet ha bisogno di una carta dei diritti" (2006) La Repubblica, available at http://www.repubblica.it/2006/11/sezioni/scienza_e tecnologia/internet-30-milioni/carta-dirittiinternet/carta-diritti-internet.html (accessed 20 Apr 2009).

${ }^{7}$ See note 5 above.

${ }^{8}$ J Balkin, "Digital Speech and Democratic Culture: A Theory of Freedom of Expression for the Information Society” (2004) 79 New York University Law Review, 42-47.

9 J Palfrey, Access Denied: The Practice and Politics of Internet Filtering (Cambridge, MA: MIT Press, 2008). 
on the delicate balance between innovation and control. ${ }^{10}$ However, the birth and development of the Internet Bill of Rights (IBR) proposal has added a more specifically European dimension to the debate, in particular thanks to the contributions of Italian scholar Stefano Rodotà. The remainder of this section will outline the perspective and vision fostered by the IBR promoters - in order to subsequently assess the feasibility and opportunity to translate those principles into a constitution-like document.

The promoters of a charter for the rights of the Internet argue that while information and communication technologies (ICTs) offer, on one hand, the possibility of increasingly wide participation to the Information Society ${ }^{11}$ and unprecedented sharing of ideas and contents, they give on the other hand room to issues of information control and manipulation from particular groups or individuals. Technologies of freedom and technologies of control live side by side.

Delivering the future to absence of rules and natural evolution might expose the global public network created by the Internet to the law "of the strongest" - not only in the sense of a progressively higher level of control by governments in the name of security, ${ }^{12}$ but also as a gradual self-imposition of the logics of the market (often the only source of rules when an institutional framework of guarantees is lacking). ${ }^{13}$ It is therefore argued that a truly accessible, both individually and collectively, public space should not be subjected to private owning, nor to public control. Object of special attention within the Internet's creation and organisation of a public space should be the new modalities of intervention and interaction, like the progressive organisation of public structures (networks), the access to online information and services, the introduction of new possibilities of control by citizens of their representatives and thus a wider availability of possibilities to intervene in decisionmaking processes, the creation of new social spaces for knowledge and information sharing. ${ }^{14}$ At the same time, the focus on positive aspects should not lead to the neglect of the "sins of the digital age," 15 such as inequality, commercial exploitation, exposure of misleading information, threats to privacy and the "tyranny" of access control. ${ }^{16}$ Interestingly, IBR discourses on these aspects seem to focus exclusively on the rights of human beings, while discussions on the rights of companies, legal entities in their own right, are absent - including for those issues in which the promotion of the rights of one group does not (necessarily) go to the detriment of the other (e.g. net neutrality).

\footnotetext{
${ }^{10}$ L Lessig, The Future of Ideas (New York: Vintage Books, 2002).

${ }^{11}$ D Lyon, The Information Society: Issue and Illusion (Oxford: Polity Press, Blackwell, 1988).

${ }^{12}$ E.g., the fight to terrorism has often been the reason for Western countries' governments, in recent years, to retain - for long periods of time - data regarding every form of electronic communication by their citizens and to deliver sensitive information to police authorities in order for them to create and archive profiles.

${ }^{13}$ See note 5 above.

${ }^{14}$ S Rodotà, Tecnopolitica. La democrazia e le nuove tecnologie della comunicazione (Roma-Bari: Laterza, 1997), at 36 and 82.

${ }^{15}$ L Brown, The Seven Deadly Sins of the Digital Age (Intermedia, 1994), at 32-37.

${ }^{16}$ H Schiller, Information Inequality: The Deepening Social Crisis in America (New York: Routledge, 1996), at 54 .
} 
The main argument of the IBR promoters can then be summarized as following. All those who see in the Internet either only the freedoms it naturally enables, or the need for regulations and constraints in the name of security, are missing a vital part of the picture: only a collective and capable use of ICTs can avoid the transformation of the Net into a controlled realm, dominated by a few actors. Furthermore, the very relevance of the Internet inasmuch as the birth of a global public space is concerned makes it necessary to guarantee and safeguard citizens' rights within that same public space through appropriate instruments.

\section{Basic principles between new and old rights: privacy as a case study}

The predictable next step of the discussion concerns the features that these "appropriate instruments" should have. As the promoters of the Bill themselves consider the right to privacy as being of crucial importance, it will be given particular attention here as a case study which will put in context the rationale behind the IBR. The instrument would, however, be aimed at protecting a number of other rights, such as: the right to be online in the first place (freedom of access and use); the right to create and share knowledge; and last, but not least, freedom of expression - a controversial theme which is central to the present debates and comes with a long history. ${ }^{17}$ An issue which has, thus far, been neglected in the IBR debate (but heavily discussed in other settings and potentially interesting to address in this one) is the realm of rights in virtual worlds and avatar rights; the question whether avatars - being the manifestation of actual people in an online medium - should have their utterances, actions, thoughts, and emotions considered to be as valid and endowed with rights as their equivalent in any other forum or through another medium. ${ }^{18}$

Rodotà argues repeatedly that the primary aspect a discipline of the Internet should take into account is privacy. ${ }^{19} \mathrm{He}$ is followed by other prominent supporters of the IBR, who argue that

In an ideal world the right to privacy would be protected by an entity with full understanding of the priorities of rights and capable in each situation to decide which right is more important. This entity also needed total knowledge of the context to be considered in order to produce the ethically correct or at least most suitable solution. Because this is impossible from a practical point of view, the basic need is to find a middle way between auto-regulation and

\footnotetext{
${ }^{17}$ W Fisher, "Freedom of Expression on the Internet" (2001) Berkman Center for Internet and Society at Harvard Law School, available at http://cyber.law.harvard.edu/ilaw/Speech/ (accessed 2 June 2009).

${ }^{18}$ R Koster, "Declaring the Rights of Players" (2000) Raph Koster's Website, available at http://www.raphkoster.com/gaming/playerrights.shtml (accessed 2 June 2009).

${ }^{19}$ See notes 5, 6 and 14 above.
} 
institutionalized control. ${ }^{20}$

As the promoters of the Bill themselves consider the right to privacy as being of crucial importance, it is taken here as a case study of the following aspects: the ways in which this right is enshrined in existing national and international instruments; whether and how an update according to the content and communication features of the Net is required; the extent to which a new instrument would be able to move from a negative to a positive conception of the right; what authorities are and should be involved in the protection of this right, and with what functions.

It is proposed that uses of personal data should be further clarified for the specific context of the Internet, with particular focus on the responsibilities of everyone concerned; the purpose(s) for which data and personal information are collected; and the acknowledgment and informed consent of the interested party. Furthermore, it should grant that the storage of personal information does not exceed a strictly necessary period of time, and allow the possibility of the interested parties to access the data in order to correct errors at any time.

Any further regulation on privacy concerns can benefit from already existent, widely ratified conventions. For example, the right to protection of personal data is enshrined in Article 8 of the Charter of Fundamental Rights of the European Union (EU). At paragraph 2, the article reads:

Such data must be processed fairly for specified purposes and on the basis of the consent of the person concerned or some other legitimate basis laid down by law. Everyone has the right of access to data which has been collected concerning him or her, and the right to have it rectified. ${ }^{21}$

Interestingly, paragraph 3 of the same article underlines the necessity of an independent authority with oversight functions. ${ }^{22}$ The rights are thus located in a realm in which public institutions are asked to fulfil a function of guarantee and control. ${ }^{23}$ This further underlines the overcoming of the negative concept of the right to privacy (as might be a "right to be left alone"), and moves it forward to a positive conception, that involves the public institutions being proactive in order to guarantee that freedom. ${ }^{24}$

\footnotetext{
${ }^{20}$ D Casacuberta, M Senges and J-M Duart, "Privacy and the need for an Internet Bill of Rights: Are there new rights in Cyberspace?" (2007) Paper presented at the GigaNet Second Annual Symposium, Rio de Janeiro, Brazil, November 11, 2007

${ }^{21}$ Charter of Fundamental Rights of the European Union 2000, art 8.2, available at http://www.europarl.europa.eu/charter/pdf/text en.pdf (accessed 20 Apr 2009).

${ }^{22} \mathrm{Ibid}$, art 8.3, "Compliance with these rules shall be subject to control by an independent authority".

${ }^{23}$ S Rodotà, "Il buio dei diritti" (2007) La Repubblica, available at http://www.repubblica.it/2007/09/sezioni/cronaca/privacy-ufficio/commento-rodota/commento-rodota.html (accessed 20 Apr 2009).

${ }^{24}$ See Rodotà, note 14 above, at 29-30.
} 
Such a discipline also implies the safeguard of the right to privacy of communications, as it is already set in many national constitutions. The Italian one, for example, reports at Article 15 that "the freedom and secrecy of communications and correspondence are inviolable." 25 The extension of such principles of freedom and secrecy should arguably be extended to the Internet-created public space, especially considering that communications and correspondence increasingly take place in virtual spaces and less often in "real" ones. Once again, this necessity is acknowledged in most national legal orders, at least within EU borders. It is argued, however, that these norms are inadequate as the competence and jurisdictions of national legal systems cannot apply to the Internet and more generally to transnational networks. If agreements and forms of judicial cooperation are lacking, it may prove difficult e.g. to find a national of one country liable for the violation of the privacy of a national of a different country. ${ }^{26}$

These remarks are considered to be all pointing in one direction: the need to reaffirm those liberties that are enshrined in international conventions and national constitutions, whilst updating them according to the content and communication features of the Net. In doing this, special care should be paid to formalise them in such a way that increases their certainty and applicability. This would best be translated pragmatically into the creation of an IBR.

\section{...Towards an Internet Bill of Rights?}

For the good and for the bad, the unprecedented change in power balances that the Internet is supporting prompts the establishment of the basic principles of the new "global citizenship": freedom of access, freedom of use, right to knowledge and to share it freely, respect to privacy, identification of new common goods. ${ }^{27}$ The idea of an IBR is born out of a desire to face and respond to the challenges posed by the evolution of the technical architecture and to legally ensure the respect of principles deemed as fundamental and intrinsically linked to the evolution of a global, "networked" public space. ${ }^{28}$

To the objection that even before considering how the IBR should be done, one should consider whether it can be done or not, its promoters respond that it is the Internet itself that suggests the way forward. Of course, the IBR will not be achieved by summoning a Constituent Assembly; innovative ways are needed, able to take into account the multiplicity of actors involved in Internet governance (i.e. states, individual citizens,

\footnotetext{
${ }^{25}$ Costituzione della Repubblica Italiana, art 15, available at http://www.quirinale.it/costituzione/costituzione.htm (accessed 20 April 2009, my translation).

${ }^{26}$ E Gelbstein and J Kurbalija, Internet Governance: Issues, Actors and Divides (Malta: The Information Society Library, 2005), at 75.

${ }^{27}$ See note 5 above.

${ }^{28}$ See note 6 above.
} 
providers, producers, entrepreneurs) - translating, into practice, a multi-stakeholder approach. ${ }^{29}$ The very nature of the Internet opposes the adoption of regulation forms according to traditional, "vertical" models involving a single authority, or multiple authorities in intergovernmental fora. Rodotà points out that the Internet is the place of pervasive discussion, universal initiatives, elaboration and sharing of contents and ideas. ${ }^{30} \mathrm{It}$ is thus hard to imagine that the adoption of an IBR would follow the traditional procedures pertaining to international conventions.

In the intentions of the IBR promoters, however, this should not mean that the content of precedent legal instruments is to be deemed as obsolete. In fact, as mentioned previously, a good starting point for any IBR is to be found in the Charter of Fundamental Rights of the European Union, due to its recognition of personal data protection as an autonomous, fundamental right, together with the overcoming of the traditional conception of privacy and the acknowledgement that the freedom of human beings cannot be achieved without the preservation of personal data. ${ }^{31}$

\section{The ongoing debate on the IBR: from the Internet Rights \& Principles coalition to the European Parliament}

The project of creating an IBR, already outlined during the World Summit on the Information Society in November $2005,{ }^{32}$ has taken a more tangible form at the Internet Governance Forum (IGF)'s first meeting of October 2006, in Athens, Greece. ${ }^{33}$ Many commentators have viewed this step as a sign of "maturity," 34 finally giving the "freedom on the Net" theme the spotlight it deserves among the wide spectrum of Internet governance issues.

The Dynamic Coalitions were born as groups "of institutions or people who agree to pursue an initiative started at the inaugural IGF meeting," 35 throughout the following year and in preparation for the second meeting that took place in November 2007 in Rio de Janeiro, Brazil. ${ }^{36}$ They can be seen as working groups on relevant subjects for Internet governance, delving into specific themes and fostering ideal contexts for research into a variety of issues.

\footnotetext{
${ }^{29} \mathrm{C}$ Padovani, "From Lyon to Geneva. What Role for Local Authorities in the WSIS Multistakeholder Approach?" (2004) The World Summit in Reflection, available at 
At the last IGF, the following coalitions were listed as active: Stop Spam Alliance, Privacy, Open Standards, Internet Bill of Rights, Access to Knowledge, Online Collaboration, Freedom of Expression, Access and Connectivity for Remote, Rural and Dispersed Communities, Linguistic Diversity, A2K@IGF, Gender and Internet Governance, Framework of Principles, Child Online Safety, Accessibility and Disability and Internet and Climate Change. ${ }^{37}$ In January 2009, the Internet Bill of Rights and the Framework of Principles for the Internet Coalitions joined forces in what has been re-baptised as the Internet Rights \& Principles Coalition, ${ }^{38}$ whose mission is to:

[C]reate a platform for the emergence and agreement on definitions of Internet Rights (a notion which encompasses all (human) rights on the Internet), an Internet Rights watch (implying the build-up of a repository of precedences and coverage of Internet Rights cases), as well as a means to translate and mainstream these Internet Rights standards into "human readable" standardized formats so users and providers of services become more aware of the rights they have on any given website or when using services. ${ }^{39}$

The discussion on modalities, time schedule and features of the project is currently open online. Some principles have already been defined between Athens and Rio, such as the multi-stakeholder approach ${ }^{40}$ and the respect of existing human rights instruments. ${ }^{41}$ However, there is a common understanding that the continuous evolution of the technical architecture should translate into the flexibility of the Bill of Rights with respect to any preexisting, predefined model, both structure- and content-wise, in its double challenge of figuring out the best ways to "implement and better define human rights and duties in the Internet environment" and the "areas and types of rights and duties [that] should be part of this work and of its results."

\footnotetext{
${ }^{37}$ The dynamic coalitions are to be found at: http://www.stopspamalliance.org/; http://igf2006.info/wiki/Privacy, http://www.cptech.org/a2k/igf/athens110206/keydocs.html; http://www.a2k-igf.org/; http://foeonline.wordpress.com/; http://igf2006.info/wiki/IGF-OCDC, http://www.pacificit.org/dc/; http://maayajo.org/spip.php?article27; http://www.A2K-IGF.org; www.itu.int/accessibility/DC.

${ }^{38} \mathrm{http}$ ///internetrightsandprinciples.org/.

${ }^{39}$ Internet Rights \& Principles Coalition, "IBR History" (2009), available at http://internetrightsandprinciples.org/node/14 (accessed 20 Apr 2009).

${ }^{40}$ WSIS Declaration of Principles 2003, at par 48-49, available at http://www.itu.int/wsis/docs/geneva/official/dop.html (accessed 20 Apr 2009): “The international management of the Internet should be multilateral, transparent and democratic, with the full involvement of governments, the private sector, civil society and international organizations. The management of the Internet encompasses both technical and public policy issues and should involve all stakeholders and relevant intergovernmental and international organizations."

${ }^{41}$ The Internet Bill of Rights Coalition, "Statement at the IGF Consultations in Geneva" (2007), on archive with the IR\&PC, available at http://internet-bill-of-rights.org/en/stmt 20070213.php until Jan 2009: "the need to build on existing statements of human rights and duties, and to interact with other related efforts. [...] the need to gather in an international environment to devote the utmost attention to this matter and advance the creation and formalization of consensus about it."
} 
Immediately after the IGF 2008 meeting in Hyderabad, India, the Coalition created a new website, with the stated aim of building a "stronger alliance with the related IGF coalitions and the secretariat in order to achieve a more prominent position of rights in the IGF agenda and mainstreaming human rights in the everyday work of the stakeholders." The new online environment is part of a larger marketing of the initiative to the public, as well as a facilitator for content contribution by the potential subjects of the IBR. While it seems clear that the road towards the Coalition's final goal is still long, its quest to increase its legitimacy as a proponent of a crucial issue, as well as its efforts to reinvent and update itself, are equally noteworthy.

Interestingly, the nexus between rights, principles and the Internet was the subject of increased attention in the early phases of the preparation of the IGF's fourth meeting, about to be held in Egypt in November 2009. The post-Hyderabad Synthesis Paper reports that "[r]ights and the Internet was recommended as the overarching theme" for the Egyptian meeting, so as to "clarify and attempt to reach consensus on how rights with respect to the Internet were defined, and how they relate to pre-existing definitions of human rights." ${ }^{\text {"42 }}$ The meeting of the IGF Multistakeholder Advisory Group held in February 2009 did not subsequently build on this recommendation ("Internet rights and principles was another proposal for an overall theme, but the view was held that this would be too specific"). ${ }^{43}$ This does, however, further confirm that the interest in the issue and the perception of its importance are present in transnational and international discussions and is, likely, a guarantee of the fact that the IBR proposal will be thoroughly reviewed and assessed.

Such interest seems to be alive in European venues as well. A request by the European Parliament's Committee on Civil Liberties, Justice and Home Affairs (LIBE) to Steve Peers, professor at the University of Essex, to produce a study on "the human rights aspects of the Internet, ${ }^{, 44}$ published in January 2009, has been followed by the LIBE's unanimous vote of a recommendation on "strengthening security and fundamental freedoms on the Internet", proposed by Stavros Lambridinis, in February $2009,{ }^{45}$ and by a public hearing of the same title held by the LIBE the following month. ${ }^{46}$ The project of creating a European IGF, hypothesized for some years, is now on its way in the form of the European Dialogue on Internet Governance (EuroDIG), whose second meeting was held in September 2009 and identified the "protection of human rights" as a key priority for today's Internet

\footnotetext{
${ }^{42}$ IGF Secretariat, IGF Third Meeting, Synthesis Paper (2008), at 63, available at http://www.intgovforum.org/cms/sec_papers_08/IGF.SynthesisPaper.Final.30.10.2008.pdf (accessed 11 May 2009).

${ }^{43}$ IGF Multistakeholder Advisory Group, 25-26 February 2009 Meeting, Summary Report (2009) at 3, available at http://www.intgovforum.org/cms/index.php/futuremeetings/313-taking-stock-of-the-hyderabadmeeting-preparing-the-igf-review-process (accessed 11 May 2009).

${ }^{44}$ S Peers, "Strengthening Security and Fundamental Freedoms on the Internet - an EU Policy on the Fight Against Cyber Crime" (2009), available at http://www.europarl.europa.eu/activities/committees/studies/download.do?file=24233 $($ accessed 30 September 2009).

${ }^{45}$ See note 3 above.

${ }^{46}$ See note 3 above.
} 
governance. ${ }^{47}$ However, it should be noted that as of now, it is hard to identify the seeds of innovation, either content- or procedure-wise, anywhere in the final press release - besides the increasingly institutionalized recognition of a possible European specificity in the Internet governance landscape that needs to be further investigated:

The protection of human rights, ensuring universal access to the Internet as a public service and promoting media literacy should be key priorities for Internet governance [...]EuroDIG supported that the Council of Europe [...] provides the secretariat to ensure the sustainability of EuroDIG, which should continue to be organised in cooperation with other organisations and stakeholders, including the European Parliament (EP). There was consensus among participants on the importance of maintaining a multistakeholder approach to Internet governance related issues. ${ }^{48}$

\section{What challenges and open issues for the IBR?}

This article has outlined the current state of the proposal for the creation and adoption of a Bill of Rights for the Internet, with a special focus on the rationale behind it as well as its promises. This concluding section is, instead, aimed at pointing out the challenges and open issues it faces, which are not to be overlooked for an impartial assessment of its likelihood of success.

\section{Possible?}

First of all, there is the question of whether creating an IBR is possible. The objection to this is that the affirmation of the need for public regulation(s) collides with the planetary character of the Net. This eliminates the possibility to individuate one and only regulatory authority or body. But even discarding unlikely options like a single state or organisation, who would be - if someone has to be - the creators and "owners" of an IBR? Existing intergovernmental organisations would probably suffer from the same in-built unbalances, occasional lack of credibility and problems of enforcement they have to face in other domains, as I have argued elsewhere. ${ }^{49}$ The signature of a baseline treaty by all, or an overwhelming majority of, countries in the world seems an unlikely outcome, and an

\footnotetext{
${ }^{47}$ European Dialogue on Internet Governance, 2009 Final Press Release, available at http://www.eurodig.org/ (accessed 30 September 2009).

${ }^{48}$ See note 47 above.

${ }^{49}$ F Musiani, "War, Security and Humanitarian Intervention in the United Nations Reform Agenda" (2008) Peace \& Conflict Review 3(1).
} 
impossible one to enforce, especially if the ratification process is to happen outside existing institutional settings.

What IBR promoters see as the alternative way to go, the multi-stakeholder approach - and its chances to preserve the open and public nature of the Internet, safeguard citizens' access to online services and foster their effective, practical and agile participation - is an interesting one; one which is, however, showing flaws alongside potential, even in the most prominent examples of its application. ${ }^{50}$ Can it be successfully applied to the case at stake, which looks especially problematic in this regard? How would this be carried out in practice? Such questions have not yet been answered satisfactorily.

\section{Needed?}

Second comes the question of whether an IBR is needed. According to the most "libertarian" voices, the Net is in itself endowed with features that enable it to maintain its overall condition of openness in face of and for a variety of actors, contents and forms of knowledge organisation. Given freely, collective contributions make possible the establishment of equally accessible, democratically organised online resources, which overcomes the barriers posed by other forms of communication ("interpret censorship as damage, and route around it" $)^{51}$ and increase the possibility of a collective critical evaluation of information. There has never been a moral structure or culture to the Internet, and it is useless to try and artificially create one at the present stage.

According to this position, what is needed is rather a bottom-up "self-enforcement" of good practices: the construction of user awareness vis-à-vis the machines they own, what they can do, how they can be exploited if taken over - and a consequent shift to an increased attribution of responsibility to oneself as a user in the first place. Kleinrock even envisages the possibility of a "slowdown in Internet use and acceptance" unless a "diminished influence by government and industry" is pursued, so as to

maintain the basic concepts that were contained in the original philosophy of the Internet, namely, that it was founded on a heritage of openness and freedom, of open research, of shared ideas and works, with no overbearing control structure, and with trust in the members of the community. ${ }^{52}$

So, why not let the Internet decide for itself? The response of the Bill's promoters is that the Internet is too much of a reality on the move to argue that its natural, sine qua non condition

\footnotetext{
${ }^{50} \mathrm{~F}$ Musiani, 'Le présent de l'IGF et de la gouvernance d'Internet : une mise à jour après Hyderabad, une évaluation à mi-chemin" (2009) Vox Internet II Article 267, available at http://www.voxinternet.fr/spip.php? article267\&lang=fr (accessed 23 April 2009).

${ }^{51}$ Quote attributed to, and then confirmed by John Gilmore of the Electronic Frontier Foundation (EFF). See http://cyber.law.harvard.edu/people/reagle/inet-quotations-19990709.html (accessed 22 April 2009).

${ }^{52}$ L Kleinrock, "The Internet Rules of Engagement: Then and Now" (2004), Technology in Society 26(2-3): 19-207
} 
of space of freedom can only be safeguarded if no regulation is established at all. The very natural freedoms fostered by the evolution of the Net are in parallel leading to an increasing number of initiatives and instruments aimed at controlling online behaviours by impeding access, supervising data, filing end users' profiles - and creating new needs, such as the safeguard of privacy on the net, that were non-existent only a handful of years ago.

\section{Suitable?}

Without detracting from the validity of this point, another relevant issue with the creation of an IBR lies in its suitability as an answer to these types of threats. It is possibly naïve of those I have called the "libertarians" to neglect the control and centralisation drives that are present in today's Internet; but it might be equally naïve of the Bill's promoters to underplay a valid counterargument, i.e. that a protection system for the majority of the issues to be covered by the IBR is basically already in place, in a plurality of legal systems and norms. Moreover, this plurality of norms is often inherent in technical devices themselves: devices that are constantly bound to change at the rapid pace of technological progress and innovation, and that might be ultimately more damaged than protected by legal measures based on a "snapshot of technology at any given time". 53

This system is already difficult enough to sort through and eventually act upon - and in front of it, the proposal of harmonisation with existing human rights instruments, rather than being a promise of increased clarity, seems more like an argument for irrelevancy. Unless it reaches an incredibly delicate balance between local and global, public and private, technical and political, the Bill is constantly risking being turned into the upper layer of this very complex scenario - an all-encompassing container that can, for the same reason, easily become very thin and rapidly fall into uselessness.

\section{Protecting users?}

A final point of debate concerns the argument that an IBR is needed to counter the progressive exclusion of end users from the possibility to be exclusive managers, through their individual capacities of access and research, of their relationship with the Net and with other users. As of today, the IBR promoters argue, we could not do without forms of mediation such as the Google or Yahoo! portals that organise the enormous quantity of available information and make them, in fact, available to end users. Without them, research on the Internet would be almost impossible, as in an uncharted continent: portals perform the function traditionally fulfilled by libraries and museums, and have probably outgrown their success, but also carry issues of information selection criteria, that are decided by few for the many.

\footnotetext{
${ }^{53}$ N Elkin-Koren, "Making Technology Visible: Liability of Internet Service Providers for Peer-to-Peer Traffic" (2006) NYU Journal of Legislation and Public Policy (9):15-61
} 
This is hardly deniable: but is a top-down imposition of rules to existing actors necessarily the way to go about it? Maybe not, according to the many practitioners of the "alternative" that are starting to populate the Internet with fully decentralised, alternative search engines, ${ }^{54}$ social online storage and exchange mechanisms,${ }^{55}$ multifunctional platforms ${ }^{56}$ mapping utilities ${ }^{57}$ - with potentially far-reaching implications for a "counter-evolution" of end users as not only producers, but managers and hosts of their own content.

\section{Concluding remarks}

In conclusion, aside and beyond its eventual translation into a regulatory instrument for the rights of Netizens, the IBR project opens interesting paths of reflection on the process of identification and recognition of rights, and on the nature of the challenges to citizens' liberties inside the global technical architecture. Its success or failure are likely to depend on the ability of its proponents to translate the complex balance between existing normativities, current viewpoints and visions of the future, into words and practice. Future discussions of the proposal should not overlook the fact that technology is a "dynamic parameter" 58 in the process of recognition of rights into written law; thus, it is possible for it to evolve and innovate at too fast a pace, and too unpredictable a direction, for any regulator to be able to follow them and avoid being either invasive or irrelevant - whatever the intended aim of the regulation: to restrict, or to protect. It is however clear that, now more than ever, all concerned parties should keep an interested eye on Internet rights debates within relevant venues, from the IGF and its dynamic coalitions to the European Parliament and its committees.

\footnotetext{
${ }^{54} \mathrm{http}: / /$ maay.netofpeers.net/.

${ }_{55}^{5 \mathrm{http}: / / \mathrm{www} . w u a l a . c o m / ; ~ h t t p: / / w w w . m o v e n p l a y . c o m / . ~}$

${ }_{57}^{56}$ http://www.tribler.org/; http://paripari.it.

${ }^{57} \mathrm{http}$ ://www.openstreetmap.fr/.

${ }^{58}$ See note 53 above.
} 


\section{References}

Balkin, J. "Digital Speech and Democratic Culture: A Theory of Freedom of Expression for the Information Society" (2004) 79 New York University Law Review, 42-47

Brown, L. The Seven Deadly Sins of the Digital Age (Intermedia, 1994)

Casacuberta, D., M. Senges and J.-M. Duart, « Privacy and the need for an Internet Bill of Rights: Are there new rights in Cyberspace? » (2007) Paper presented at the GigaNet Second Annual Symposium, Rio de Janeiro, Brazil, November 11, 2007

Charter of Fundamental Rights of the European Union 2000, art 8.2, available at http://www.europarl.europa.eu/charter/pdf/text en.pdf

Costituzione della Repubblica Italiana, available at http://www.quirinale.it/costituzione/costituzione.htm

Di Maggio, P. et al., "Social Implications of the Internet" (2001) 27 Annual Review of Sociology, 307-336

Elkin-Koren, N. "Making Technology Visible: Liability of Internet Service Providers for Peer-toPeer Traffic" (2006) NYU Journal of Legislation and Public Policy (9): 15-61

European Parliament, Report with a proposal for a European Parliament recommendation to the Council on strengthening security and fundamental freedoms on the Internet (2008/2160(INI)) (25 Feb 2009) available at http://www.europarl.europa.eu/sides/getDoc.do? type $=$ REPORT\&reference $=$ A6-2009-0103\&language $=$ EN\#_part1_def11

European Parliament, Strengthening Fundamental Freedoms and Security on the Internet Public Hearing (5 Mar 2009) available at http://www.europarl.europa.eu/eplive/expert/shotlist page/20090304SHL50970/default_en.htm

Fisher, W. "Freedom of Expression on the Internet" (2001) Berkman Center for Internet and Society at Harvard Law School, available at http://cyber.law.harvard.edu/ilaw/Speech/

Gelbstein, E. and J. Kurbalija, Internet Governance: Issues, Actors and Divides (Malta: The Information Society Library, 2005)

IGF Secretariat, IGF Third Meeting, Synthesis Paper (2008), available at http://www.intgovforum.org/cms/sec papers 08/IGF.SynthesisPaper.Final.30.10.2008.pdf.

IGF Multistakeholder Advisory Group, 25-26 February 2009 Meeting, Summary Report (2009), available at http://www.intgovforum.org/cms/index.php/futuremeetings/313-taking-stock-of-thehyderabad-meeting-preparing-the-igf-review-process.

Information Policy, "European Parliament asks for respect of human rights on the Internet" (13 Apr 2009), available at http://www.i-policy.org/2009/04/european-parliament-asks-for-respect-ofhuman-rights-on-the-internet.html 
Lessig, L. The Future of Ideas (New York: Vintage Books, 2002).

Lyon, D. The Information Society: Issue and Illusion (Oxford: Polity Press, Blackwell, 1988).

Koster, R. "Declaring the Rights of Players" (2000) Raph Koster's Website, available at http://www.raphkoster.com/gaming/playerrights.shtml

Kleinrock, L. "The Internet Rules of Engagement: Then and Now" (2004), Technology in Society 26(2-3): 19-207.

Musiani, F. "Le présent de l'IGF et de la gouvernance d'Internet : une mise à jour après Hyderabad, une évaluation à mi-chemin" (2009) Vox Internet II Article 267, available at http://www.voxinternet.fr/spip.php?article267\&lang=fr

Musiani, F. "War, Security and Humanitarian Intervention in the United Nations Reform Agenda" (2008) Peace \& Conflict Review 3(1).

Oestreich, G. Geschichte der Menschenrechte und Grundfreiheiten im Umriß (Berlin: Duncker \& Humblot, 1978).

Padovani, C. "From Lyon to Geneva. What Role for Local Authorities in the WSIS Multistakeholder Approach?" (2004) The World Summit in Reflection, available at http://cyber.law.harvard.edu/wsis/Padovoni_Lyon.html

Peers, S. "Strengthening Security and Fundamental Freedoms on the Internet - an EU Policy on the Fight Against Cyber Crime" (2009), available at http://www.europarl.europa.eu/activities/committees/studies/download.do?file $=24233$

Palfrey, J. Access Denied: The Practice and Politics of Internet Filtering (Cambridge, MA: MIT Press, 2008).

Paolozzi, E. "Universalità e storicità dei diritti umani da Locke a Croce" (2000) Fondazione Luigi Einaudi, Scuola di Liberalismo, available at http://www.fondazione-

einaudi.it/Download/123-127.pdf

Rodotà, S. "Una Costituzione per Internet" (2006) La Repubblica, available at http://www.repubblica.it/2006/06/sezioni/scienza e tecnologia/regole-internet/regoleinternet/regole-internet.html

Rodotà, S. "Perchè Internet ha bisogno di una carta dei diritti" (2006) La Repubblica, available at http://www.repubblica.it/2006/11/sezioni/scienza e tecnologia/internet-30-milioni/carta-dirittiinternet/carta-diritti-internet.html

Rodotà, S. Tecnopolitica. La democrazia e le nuove tecnologie della comunicazione (Roma-Bari: Laterza, 1997).

Rodotà, S. "Il buio dei diritti" (2007) La Repubblica, available at 
http://www.repubblica.it/2007/09/sezioni/cronaca/privacy-ufficio/commento-rodota/commentorodota.html

Schiller, H. Information Inequality: The Deepening Social Crisis in America (New York:

Routledge, 1996).

WSIS, Tunis Agenda for the Information Society (2005).

WSIS, Declaration of Principles (2003).

\section{Webography}

http://internetrightsandprinciples.org

http://maay.netofpeers.net/

http://www.wuala.com/

http://www.movenplay.com/

http://www.tribler.org/

$\underline{\text { http://paripari.it. }}$

http://www.openstreetmap.fr/

http://cyber.law.harvard.edu/ 